\title{
MANNER ADVERBIAL COMPLEMENT IN BOSNIAN LANGUAGE
}

Halid Bulić1

Faculty of Philosophy, University of Tuzla

Received: 20.06.2011

Accepted: 29.10 .2011
Original scientific paper

UDC: $811.163 .43 ` 367.624$

\begin{abstract}
Some verbs require that the sentence in which they serve as predicate must state the specific circumstances and if it is absent the sentence would be grammatically incorrect. This means that the valence of certain verbs require that they must be complemented by specific adverbial. Adverbials whose presence is necessary for grammatical correctness of sentences are adverbial complements. This paper discusses the facts of manner adverbial complement and states examples of its use. It also analyzes the situation in which this complementation can be realized in the form of the vocative.
\end{abstract}

Key words: complement, adverb, adverbial complement, manner, manner adverbial complement, vocative, Bosnian language

\section{INTRODUCTION}

1. Manner adverbial complement has already been mentioned in the linguistic literature and it is confirmed in the corpus our research is based on. Samardžija (1986, p. 20) states examples of this complementation and it is also recognized by Palić (2007, p. 38-39) in his monography Sintaksa i semantika načina. It is mentioned in Gramatika srpskog jezika (2004, p. 238) by Stanojčić and Popović, but in Sintaksa savremenoga srpskog jezika (Piper et al. 2005, p. 498-499) it is referred to as qualification complementation.
2. Manner adverbial complement can be seen in the following examples:

(1) Djeca se *(lijepo) $)^{2}$ ponašaju. (Conv.) Njegova pjesma *(dobro) zvuči. (Conv.) On se tad ponio *(kukavički). (Conv.) ...kako su se domaćini

1 Correspodence to:

Halid Bulić, Faculty of Philosophy, University of Tuzla

Dr Tihomila Markovića 1, 75000 Tuzla, B\&H.

Phone: +387334034

E-mail: halidb10@yahoo.com

2 An asterisk before an open bracket means that a word or construction inside the brackets is necessary for grammatical correctness of the sentence. 
u Rusiji potrudili da se osjećaju *(kao kod kuće). $\left(\mathrm{A}^{3}, 15\right)$ Izgledala je *(grozno)... (A, 20) ...ljudi koji *(lijepo) izgledaju imaju veće šanse... (A, 28) Zaista ne želim da zvučim *(glupo)... (A, 36) ...u dvoznačnoj će se smrti / jastuk ponašat *(poput / Nojeva splava). (ABI, 79) ...koji je čitavi Prvi svjetski rat proveo *(izvještavajući sa balkanskih ratišta). (KZT, 22) Finalni podaci doimali su se *(zastrašujuće). (KZT, 57)

Istovremeno, počele su se ponašati *(agresivno i pakosno)... (KZT, 77) Abažuri nad stolovima izgledaju *(kao cvjetovi okrenuti naopačke). $(\mathrm{AKK}, 8)$...i pri tome je djelovao *(ozbiljno)... (AKK, 29) ...svaku vlast možemo predstaviti *(u vidu trougla)... (AKK, 52) ...želite da se sve odvija *(vratolomnom brzinom). (AKK, 61) ...on to samo kad hoće da zvuči *(,urbano“) (AKK, 66) ...kada te tretiraju *(kao slugu, kao portira, ili kao ličnu sekretaricu). (AKK, 131) Ja se *(vrlo nelagodno) osjećam (ATU, 116) Drži se *(kao kakav stranac)... (ĆSD, 5) Sada to izgleda *(kao žrtvovanje)... (AIT, 95)

3. Manner complement can occur with the verb trajati, when it means 'taking place': (2) *(Tako) je trajala njihova velika uzajamnost i njihova ljubav... (AIT, 77)

4. Manner complement often comes with verbs which in addition to it require or permit substantive complement in the form of dative case with a preposition:

3 The sources the examples are taken from in this text are marked by the following contractions: A - Azra, magazine, year XII, number 647, July 22th, 2009; ABI - Amir Brka, Izložba sitnih životinja, Vrijeme, Zenica, 2003; KZT Karim Zaimović, Tajna džema od malina, Civitas, Sarajevo, 2005; AKK - Asmir Kujović, Ko je zgazio gospođu Mjesec, 3rd Edition, Vrijeme, Zenica, 2002; ATU - Amir Talić, Uglovima šetaju tajne: izabrane pjesme, Centar za kulturu i obrazovanje, Tešanj, 2001; ĆSD - Ćamil Sijarić, Drvo kraj Akova, Univerzitetska riječ, Nikšić, 1990; AIT - Alija Isaković, Taj čovjek, Civitas, Sarajevo, 2004; SKP - Skender Kulenović, Ponornica, Civitas, Sarajevo, 2004.
(3) On se prema njima *(strogo) postavio. (Conv.) Odnosite se prema njoj *(lijepo). (Conv.) ...i *(kako) se drži prema ljudima. (SKP, 48) ...postupio bih prema njemu * (gore nego onda u Kairu). (SKP, 101) 5. It is quite interesting that manner complementation is not mentioned as adverbial complemention in Gramatka srpskohrvatskog jezika za strance (Mrazović \& Vukadinović 1990, p. 465-468); however some adverbials with manner meanings are presented as predicative complements. This is case with sentences containing verb ponašati se and izgledati as its predicates (usp. Mrazović \& Vukadinović 1990, p. 469).

In Sintaksa savremenoga srpskogjezika (Piper etal., 2005 , p. 495) in some sentences adverbial manner complementation is considered to be adverbial predicates: Ceo taj predeo izgleda nestvarno. Tvoj otac se dobro drži .

In our opinion, complement to the verb ponašati se is not a predicative, but a manner adverbial complement (cf. Palić, 2007, p. 38-39). The verb izgledati can be complemented both by predicative (On izgleda lijep 'He seems nice') and adverbial manner complement (On izgleda lijepo 'He looks nice') and in those cases it has a different meaning. 6. Verb postupati which is usually complemented by manner adverbial complement in the administrative-legal style of Bosnian language has developed a meaning which does not have to be complemented by manner adverbial:

(4) U tom predmetu postupao je tužilac N. N. ('Prosecutor N. N. was in charge of this case')

7. Some verbs that require manner complement can make grammatical correct sentence without manner complements in cases where they present a special manner meaning. This is case with the verbs postaviti se, držati se and provesti se when 
they mean the following 'dobro se postaviti' ('take a good stand' or 'have a good attitude'), 'dobro se držati' ('handle it well') and 'dobro se provesti' ('have a good time'):

(5) Znao sam se postaviti. (AIT, 97)

(6) Oni se još drže. (Conv.)

(7) Jučer smo se baš proveli. (Conv.)

However the fact that other meanings cannot be expressed without specifying manner adverbial complements indicates that manner adverbial by the same verbs is not optional:

(8) *Znao sam se postaviti. ('Znao sam se loše / pogrešno postaviti' /'I could take a bad stand' or ' I could have a wrong attitude / oppinion'/)

(9) *Oni se još drže. ('Oni se još loše / osrednje / slabo drže' /'They still handle it badly / not so well'/) (10) *Jučer smo se baš proveli. ('Jučer smo se baš loše proveli' /'We had a really bad time yesterday' / 'It was not quite a fun yesterday' / 'It was totally bad / terrible yesterday'/)

8. One meaning of the verb obraćati se must be complemented by manner adverbial:

(11) On joj se obraća *(tako / imenom / sa kolegice). In this case, the manner meaning partially has a meaning of instrument, but anaphora of marked constructions is clearly manner (tako). In this case the most interesting is that vocative with preposition $s(a)$ can occur as a possible complement, as a part of sentence structure. The grammarians has always denied that vocative can be part of sentence structure. There are exeptions only in oral literature in the need for the ten-syllable line where some masculine nouns can be used in the vocative in the position of the subject and predicate. This vocative can always be replaced by the nominative. The above example is not from oral literature, the noun kolegica is not masculine noun, and cannot be replaced by nominative or instrumental or case-prepositional phrase:
(12) *On joj se obraća sa kolegica / kolegicom / pomoću kolegice / nečim...

We can seek the origin of vocative construction in other constructions (e.g. instrumental) in depth sentence structure, but on the surface structure it appears as an unavoidable fact and as something that deserves to enter the grammatical descriptions as well as valence dictionaries.

\section{CONCLUSION}

This paper shows that there is manner adverbial complementation in Bosnian language and it also states the examples of its use. It is also proved that such complementation can be expressed by vocative.

\section{REFERENCES}

- Mrazović, P. \& Vukadinović Z. (1990). Gramatika srpskohrvatskog jezika za strance [Grammar of SerboCroatian Language for Foreigners]. Novi Sad, Serbia. Izdavačka knjižarnica Zorana Stojanovića, Sremski Karlovci; Dobra vest.

- Palić, I. (2007). Sintaksa i semantika načina [The Syntax and Semantics of Manner]. Sarajevo, B\&H: Bookline.

- $\quad$ Piper, P., Antonić, I., Ružić, V., Tanasić S., Popović, Lj. \& Tošović, B. (2005). Sintaksa savremenoga srpskog jezika. Prosta rečenica. Prilozi gramatici srpskog jezika [The Syntax of the Modern Serbian Language. Simple Sentence. Contributions for Grammar of the Serbian Language]. Belgrade, Serbia: Institut za srpski jezik SANU, Beogradska knjiga, Matica srpska.

- Samardžija, M. (1986). Dopune u suvremenom hrvatskom književnom jeziku [Complements in the Modern Croatian Literary Language]. Radovi Zavoda za slavensku filologiju. 21, Zagreb, Croatia.

- $\quad$ Stanojčić, Ž. \& Popović LJ. (2004). Gramatika srpskoga jezika. Udžbenik za I, II, III i IV razred srednje škole [Grammar of the Serbian Language. A Textbook for the I, II, III and IV Class of High School]. Belgrade, Serbia: Zavod za udžbenike i nastavna sredstva. 